Prosiding Penelitian \&

Pengabdian Kepada

Masyarakat e ISSN : 2581-1126

p ISSN : 2442-448X
Vol 5, No: 2

\title{
Hubungan Kekerasan Emosional Yang Dilakukan Oleh Orangtua Terhadap Perilaku Remaja
}

\author{
Vani Wulandari, Nunung Nurwati \\ vani@gmail.com; nunung.nurwati@unpad.ac.id
}

\begin{abstract}
ABSTRAK
Penelitian ini bertujuan untuk mengetahui apakah terdapat dampak kekerasan emosional yang dilakukan oleh orangtuanya apakah hal tersebut dapat menganggu perilaku remaja yang mengalami kekerasan emosional tersebut. Kekerasan emosional yang dilakukan oleh orangtua baik secara sengaja maupun tidak sengaja dapat mempengaruhi perilaku remaja salah satu dampaknya adalah dapat membuat perilaku remaja menyimpang. Karena pada masa remaja cenderung memerlukan kehangatan dan keserasian dalam keluarganya serta membutuhkan dukungan emosional orangtua bila mengalami kekecewaan dalam pergaulannya. Akan tetapi, terkadang orangtua tidak begitu memahami keadaan emosional remaja yang membuat remaja tersebut tidak mendapatkan dukungan emosional yang baik. Kekerasan emosional yang dilakukan dapat berupa kekerasan emosional secara verbal maupuun fisik. Hal ini, dapat mengakibatkan terjadinya kekerasan emosional yang dilakukan oleh orangtua terhadap remaja sehingga dapat mempengaruhi perilaku remaja tersebut.
\end{abstract}

Kata kunci: Kekerasan emosional, perilaku remaja.

\section{Pendahuluan}

Masa remaja merupakan masa transisi dimana remaja memiliki rasa keraguan akan peran yang harus dilakukannya. Status remaja yang tidak jelas ini juga menguntungkan karena status tersebut memberi waktu kepada mereka untuk mencoba gaya hidup yang berbeda dan menentukan pola perilaku, nilai dan sifat yang sesuai bagi dirinya (Hurlock, 1980). Hal ini membuat karakteristi remaja yang sedang dalam tahap pencarian identitas atau pencarian jatidiri menjadi rentan untuk menimbulkan permasalahan. Salah satu perilaku remaja yang kerap menjadi permasalahan adalah tindakan perilaku menyimpang. Bahkan tidak jarang bahwa remaja dapat memiliki perilaku menyimpang. Banyak kasus terjadi karena perilaku penyimpangan remaja mulai dari perilaku yang tidak dapat diterima secara sosial, pelanggaran, hingga tindakan-tindakan kriminial (Santrock, 1995).

Sebagai orangtua yang baik sering melalukan berbagai upaya untuk melindungi anak, namun terkadang perlakuan tersebut berlebihan.
Sehingga hal tersebut justru membuat ketakutan terhadap anak. Salah satu contoh yang dapat dilihat saat orangtua melarang anaknya untuk melakukan sesuatu yang berbahaya ataupun berlawanan dengan keyakinan orangtua. Orangtua biasanya akan melarang dengan tindakan verbal, bahkan kadang disertai dengan ancaman ataupun kekerasan emosional, meskipun perlakuan orangtua terhadap anaknya suka keliru. Mereka merasa bahwa hal tersebut biasa saja selama tidak melakukan kekerasan fisik terhadap anaknya. Padahal kekerasan fisip maupun psikis memiliki dampak yang sama fatalnya bagi berkembangan psikologi mental anak.

Di dalam sebuah riset yang dibakukan dalam jurnal JAMA Psychiatry, menyebutkan fakta bahwa anak yang mengalami trauma kekerasan apapun bentuknya akan tumbuh dengan berbagai masalah perilaku. Ini bisa berupa kecemasan, depresi agresi hingga pemberontakan. David Vachon dari McGill University di Montreal mengungkapkan, meskipun ada berbagai tipe kekerasan terhadap anak hal itu sebenarnya sama beratnya. Tidak ada istilah bahwa kekerasan emosional yang dilakukan orangtua lebih ringan 
dibandingkan kekerasan fisik terhadap perilaku anak. Anak yang merupakan korban kekerasan dalam bentuk apapun menunjukkan gejala masalah perilaku yang sama.

Banyak faktor yang mengakibatkan remaja memiliki perilaku penyimpangan seperti keluarga, sekolah, teman sepermainan dan sebagainya. Banyak yang berpendapat bahwa keluarga adalah faktor utama dalam pembentukan masalah emosional pada anak yang dapat mengarah pada masalah sosial adalam jangka panjang (Siegel \& Welsh, 2001). Orangtua dari anak yang terlibat memiliki perilaku penyimpangan remaja biasanya gagal dalam memberikan penguatan pada perilaku positif anak diusia dini. Oleh karena itu, tidak jarang anak mendapatkan perlakuan yang tidak seharusnya atau kekerasan di dalam rumah karena kurangnya keterlibatan orangtua secara positif dalam perkembangan anak hingga beranjak remaja. Secara teoritis, kekerasan terhadap anak dapat diartikan sebagai peristiwa kekerasan fisik, mental atau seksual yang umumnya dilakuka oleh orang yang mempunyai tanggung jawab terhadap kesejahteraan anak.

\section{Kajian Pustaka}

Kekerasan emosional dapat diartikan sebagai sikap atau perilaku yang dapat menganggu perkembangan sosial ataupun kesehatan mentak anak. Kekerasan emosional juga disebut sebagai kekerasan verbal, mental ataupun kekerasan psikologis. Menurut Moffat (2003). Terdapat efek jangka panjang dari kekerasan emosional yang dapat berakibat buruk bagi perkembangannya pada masa remaja dan dewasa nanti dan perilaku anak mungkin akan menjadi antisocial. Kemungkinan lain adalah anak akan terlibat dalam penganiayaan baiik secara fisik maupun emosional (Moffat, 2003).

Menurut Jessor (1997) terbentuknya perilaku kenakalan pada remaja dianggap sebagai dampak dari aspek psikososial pada remaja. Jessor mengemumakan pendapatnya tentang perilaku bermasalah (Problem Behaviour Theory) bahwa perilaku menyimpang remaja dipengaruhi oleh tiga aspek yang saling berhubungan. Aspek pertama, adalah kepribadian yang meliputi nilai individual, harapan dan keyakinan pada remaja. Aspek kedua yaitu sistem lingkungan yang diterima oleh remaja seperti pada lingkungan keluarga ataupun lingkuang teman sebayanya. Aspek terkahir adalah sistem perilaku yang merupakan cara yang diplih remaja untuk berperilaku dalam kesehariannya.

Menurut Jessor (1997) terbentuknya perilaku kenakalan remaja dianggap sebagai dampak dari aspek psikososial pada remaja tersebut. Dalam teori perilaku bermasalah (Problem Behaviour Theory) yang dijelaskan oleh Jessor menjelaskan bahwa terbentuknya perilaku menyimpang remaja dipengaruhi oleh tiga aspek yang saling berhubungan yaitu kepribadan yang meliputi nilai individual, harapa dan keyakinan pada remaja; sistem lingkungan yang diterima oleh remaja seperti pada lingkungan keluarga atau teman sebaya; dan sistem perilaku yang merupakan cara yang dipilih remaja untuk berperilaku dalam kesehariannya.

Patterson (1992) juga menjelaskan penyebab munculnya perilaku kenakalan pada remaja juga adalah dengan remaja yang bertindak agresi, tinggal di lingkungan keluarga yang mengalam tingkat kekerasan yang tinggi antara orangtua dan anak. Pola tindakan agresi dalam keluarga muncul dari perilaku interaksi yang agresif antar anggota keluarga sehingga hal ini menyebabkan anggota lainnya mengikuti untuk melakukan perilaku agresi. Anak yang menerima kekerasan dari orangtua akan melakukan tindakan kekerasan untuk melawan dan menjauhkan dirinya dari kekerasan yang dilakukan oleh orangtua. Hal ini akan menjadi sebuah siklus yang terus berputar dalam keluarga tersebut (Patterson dkk., 1992).

Perilaku kekerasan yang dijelaskan Patterson dalam Coercive Familty Theory (1992) meliputi perilaku yang tidak layak yang diberikan oleh orangtua kepada anaknya seperti membentak, mencaci serta kurangnya pemberian penguatan positif pada anak. selanjutnya Patterson (1994) menjelaskan bahwa adanya tndakan kekerasan oleh orangtua pada anak dapat meningkatkan resiko anak terlibat 
Prosiding Penelitian \&

Pengabdian Kepada Masyarakat e ISSN : $2581-1126$

p ISSN : 2442-448X
Vol 5, No: 2
Hal: $132-136$ permasalahan perilaku yang meliputi kenakalan remaja.

Selain karena siklus kekerasan yang
terjadi dalam keluarga, Patterson juga
menjelaskan adanya proses modeling pada anak
yang menjadi korban kekerasan oleh orangtuanya, sehingga resiko kenakalan akan sangat tinggi pada anak tersebut. Proses modeling akan terjadi ketika anak mengamati cara orangtua dalam bersikap. Ketika ia terbiasa mel ihat orangtuanya menyelesaikan suatu permasalahan dengan tindakan agresi, maka ia juga akan melakukan kekerasan dalam bersikap.

Remaja yang menjadi korban kekerasan akan meniru cara orangtuanya dalam bersosialisasi. Hal tersebut akan membuat remaja memiliki tingkat agresi yang tinggi ketika berada di luar rumah. Remaja dengan tingkat agresi tinggi akan dijauhi oleh remaja normal yang tidak memiliki gaya sosialisasi agresif.

Oleh sebab itu menurut Patterson (1982), remaja korban kekerasan emosional yang bersifat agresif akan lebih sering bersosialisasi dengan remaja lain yang memiliki karakteristik yang sama. Dengan begitu resiko untuk melakukan tindakan kenakalan atau pelanggaran akan semakin besar. Hal inilah yang menjadi dampak dari proses belajar remaja korban kekerasan emosional pada perilaku orangtuanya, yang dapat membawa ia terlibat dalam perilaku kenakalan remaja.

\section{Metode penelitian}

Dalam penelitian ini menggunakan metode kualitatif dengan menggunakan studi literature yaitu serangkaian kegiatan yang berkenaan dengan metode pengumpulan data pustaka, membaca dan mencatat serta menolah bahan penelitian (Zed, 2008:3). Metode kualitatif dengan mengedepankan studi literature yang dipilh oleh peneliti bertujuan untuk mendapatkan data melalui eksplorasi dari studi literature mengenai dampak kekerasan emosional yang dilakukan oleh orangtua yang dapat mempengaruhi perilaku remaja.
Untuk memudahkan penulis, kajian ini dilakukan secara sistematis melalui beberapa langkah yang diambil. Langkah pertama adalah mengumpulkan jurnal-jurnal ataupun buku terkait dengan kekerasan emosional yang dilakukan orangtua terhadap perilaku remaja.

Data yang dikumpulkan untuk dipergunakan dalam studi kasus adalah Data Sekunder yang merupakan data pendukung yang bersumber dari literature maupun referensi yang ada mengenai kekerasan emosional yang dilakukan oleh orangtua terhadap perilaku remaja dimana.

\section{Hasil Penelitian dan Pembahasan}

Dalam penelitian ini semakin tinggi kekerasan emosional yang diterima oleh seorang anak, maka semakin besar pula resiko anak tersebut pada kecenderungan kenakalan remaja. Begitu pula sebaliknya, semakin rendah perlakuan Kekerasan emosional yang diterima anak, maka makin kecil resikonya dalam kecenderungan kenakalan remaja.

Menurut Jessor (2003), faktor resko yang dapat memicu kecenderungan kenakalan pada remaja akan timbul apabila orangtua menjadi model yang tidak baik pada anaknya. Oleh karena itu, dalam perkembangan perilaku remaja orangtua adalah model utama dalam perilaku anak sehingga orangtua berperan sebagai faktor resiko ataupun faktor protektif pada kecenderungan perilaku kenakalan pada anak. perilaku kenakalan tersebut dapat melanggar norma-norma sosial yang ada seperti mengkonsumsi minuman beralkohol, merokok, menggunakan zat-zat berbahaya dan lain sebagainya.

Jessor dan kawan-kawan (1991) juga menjelaskan bahwa perilaku beresiko pada remaja tidak hanya disebabkan oleh satu faktor. Akan tetapi perilaku tersebut dihasilkan dari interaksi yang komplek antara remaja dengan lingkungannya. Hal ini yang oleh Jessor disebutkan sebagai adanya faktor psikososial yang membentuk perilaku seorang remaja. 
Hal ini berarti faktor penyebab dari perilaku kenakalan remaja bukan hanya perilaku kekerasan emosional yang dilakukan oleh orangtuanya. Akan tetapi, faktor lingkungan juga dapat mempengaruhi perilaku kenakalan remaja. Karena faktor psikososial yang telah diisebutkan Jessor diatas adalah faktor yang saling berinteraksii dengan remaja dimana remaja akan membentuk sebuah perilaku yang mempengaruhi dirinya sendiri. kepribadian meliputi nilaii-nilai yang dipegang oleh seseorang, sikap, keyakinan dan kontrol diri. Sedangkan lingkungan meliputi teman sebaya, sekolah, keluarga dan lingkungan tempat tinggal remaja serta bagaiman remaja memaknai lingkungannya tersebut.

Kedua faktor tersebut saling berinteraksi sehingga membentuk faktor ketiga yaitu perilaku remaja atau dalam hal ini adalah perilaku beresko pada remaja. Baik faktor kepribadian maupun faktor lingkungan memiliki dua peran penting yakni sebagai pelindung dan pemicu resiko perilaku penyimpangan pada remaja.

Lingkungan keluarga yang menjadi salah satu faktor pelindung dalam perilaku kenakalan remaja akan tetapi, jika keluarga dapat menurunkan resiko anak terlibat pada perilaku penyimpangan. Sebaliknya, jika keluarga melakukan kekerasan secara emosional kepada anak hal ini akan menjadi faktor pemicu resiko pada anak dimana anak akan menjadi faktor pemicu keterlibatan anak pada tindakan kenakalan.

Seperti yang telah dijelaskan sebelumnya, bahwa aspek psikososial yang menyebabkan seorang remaja terlibat kenakalan bukan hanya faktor keluarga saja tetapi banyak faktor lainnya yang dapat mempengaruhi anak berperilaku menyimpang seperti teman sebaya dan lingkungan sekolah atau lingkungan bersosialisasi anak tersebut. Hal ini akan menjadi salah satu penyebab hubungan lemahnya antara kekerasan emosional pada anak dan kecenderungan perilaku penyimpangan pada remaja dalam penelitian ini.

\section{Remaja yang menjadi kekerasan} emosional oleh orangtuanya namun memiliki lingkup pertemanan yang baik, hal ini dapat menjadi pelindung dari resiko kenalakan. Remaja yang memiliki lingkup pertemanan yang baik akan memiliki resiko kenakalan yang rendah, sebaliknya jika remaja yang memiliki lingkup pertemanan dengan remaja yang memiliki resiko dapat meningkatkan kemungkinan terlibatnya perilaku kenakalan remaja.

Hal tersebut sejalan dengan penjelasan yang diberikan Havighurst (1972) dalam Sarwono (1989) yang menjelaskan bahwa remaja memiliki kecenderungan untuk lebih dengan teman sebayanya dibandingkan dengan keluarganya. Seorang yang sudah beranjak remaja akan melepaskan diri dari ketergantungan emosi orangtua dan orang dewasa lainnya. Teman sebaya yang memiliki peran besar terhadap terbentuknya kecenderungan kenakalan pada remaja.

Berdasarkan analisis kenakalan remaja sangat beragam. Bentuk kenakalan yang memiliki intensitas yang tinggi adalah jenis kenakalan yang melanggar status. Kenakalan tersebut seperti membolos, menyontek, melarikan diri dari sekolah bahkan tidak jarang bahwa remaja tersebut tidak memiliki sopan santun terhadap gurunya. Tampaknya ada pengaruh lingkungan teman sebaya pada kecenderungan kenakalan remaja.

Berdasarkan analisis gender yang dilakukan dapat diketahui bahwa tingkat kenakalan remaja lebih tinggi pada remaja lakilaki. Sedangkan pada aspek kekerasan emsional, kedua baik laki-laki maupun perempuan memiliki nilai relative sama. Hal ini menjadi salah satu bukti bahwa kekerasan pada anak tidak sepenuhnya berperan penting bagi pembentukan perilaku anak. Remaja laki-laki dan perempuan yang mengalami kekerasan emosional yang sama menunjukkan bahwa kekerasan emosional tidak sepenuhnya membentuk perilaku kenakalan remaja.

\section{Kesimpulan}

Berdasarkan hasil analisis dapat disimpulkan bahwa dari dampak kekerasan emosional yang dilakukan oleh orangtua terhadap perilaku remaja memiliki dampak yang tinggi 


\begin{tabular}{|c|c|c|c|c|}
\hline $\begin{array}{c}\text { Prosiding Penelitian \& } \\
\begin{array}{c}\text { Pengabdian Kepada } \\
\text { Masyarakat }\end{array}\end{array}$ & $\begin{array}{c}\text { e ISSN : 2581-1126 } \\
\text { p ISSN : 2442-448X }\end{array}$ & Vol 5, No: 2 & Hal: $132-136$ & Juli 2018 \\
\hline
\end{tabular}

terhadap perilaku kenakalan remaja. Hal tersebut dikarenakan keluarga adalah faktor utama untuk perkembangan perilaku remaja. Remaja yang mengalami kekerasan emosional oleh orangtuanya memiliki kecenderungan melakukan kenakalan remaja daripada remaja yang tidak menjadi korban kekerasan emosional oleh orangtuanya. Akan tetapi, faktor kekerasan emosional yang dilakukan oleh orangtuanya bukan hanya faktor utama yang menjadikan berperlaku kenakalan remaja. Hal ini dikarenakan adanya faktor lain selain kekerasan yang dilakukan oleh orangtua seperti faktor lingkungan teman sebaya dan lingkungan sekolah.

\section{DAFTAR PUSTAKA}

Berger, KS. (2000). The Developing Person Through Childhood and Adolescence. New York: Worth Publishers.

Hurlock, E.B. (1980). Psikologi Perkembangan: suatu pendekatan Sepanjang Rentang Kehidupan (terjemahan oleh Istiwidayanti). Jakarta: Erlangga.

Jessor, R., \& Jessor, S. L. (1977). Problem behavior and psychosocial development: A longitudinal study of youth. New York: Academic Press.

Jessor, R., Turbin, M.S., Costa, F.M., Dong, Q., Zhang, H., \& Wang, C. (2003). Adolescent Problem Behavior in China and The United States: A Cross-National of Psychosocial Protective Factors. Journal of Research on Adolescence.

Moffatt, G. (2003). Wounded Innocents and Fallen Angels : Child Abuse and Child Aggression. Praegar Publisher.

Patterson, G. R., Reid, J. B., \& Dishion, T. J. (1992). Antisocial Boys. Eugene, OR: Castalia.

Sarwono, S.W. (1989). Psikologi Remaja. Jakarta: PT. Raja Grafindo Persada.

Suyanto, B., \& Hariadi, S. (2002). Krisis dan Child Abuse. Surabaya: Airlangga University PressThornberry,

Hari, Ananto. 2016. Dampak Psikologis Kenakalan Remaja. Inti pesan http://www.intipesan.com/sp-29865/ 